\title{
Mucuna pruriens seeds given in broiler diets on growth performance and carcass yield
}

\section{Semillas tratada de Mucuna pruriens en dietas para pollos de engorda sobre el comportamiento productivo y rendimiento en canal}

\author{
Luis Sarmiento-Franco ${ }^{1}$, Francisco López-Sántiz ${ }^{1}$, Ronald Santos-Ricalde ${ }^{1 *}$ (๑), Carlos Sandoval-Castro ${ }^{1}$ \\ ${ }^{1}$ Facultad de Medicina Veterinaria y Zootecnia, Universidad Autónoma de Yucatán, Km 15.5 Carretera Mérida-Xmatkuil, Mérida, Yucatán, \\ México. \\ *Corresponding author: rsantos@correo.uady.mx
}

Scientific note received: April 27, 2018 accepted: November 07, 2018

\begin{abstract}
The effects of Mucuna pruriens (MP) seeds soaked in water (WMP), acetic acid (AAMP) or calcium hydroxide (CHMP) solution + boiling on both its L-Dopa content and the productive performance of broiler chickens were evaluated. The experiment included a control without MP (C). The CHMP treatment reduced $71 \%$ of L-Dopa in comparison to AAMP $(53 \%)$ or WMP $(41 \%)$. In the starter phase, the AAMP group had the lowest live weight gain $(p<0.05)$ and the highest feed conversion ratio than $C(p<0.05)$. Broilers fed with CHMP and the $C$ did not differ $(p>0.05)$. In the finisher phase, there was not statistical difference in any of the variables evaluated $(p>0.05)$. Differences were not observed in carcass yield $(p>$ $0.05)$, but the broilers fed with WMP or AAMP had a heavier liver than birds on $C$ group $(p<0.05)$. Results showed that $25 \%$ of CHMP can be used as ingredient in broiler diets.
\end{abstract}

Key words: Feed intake, L-Dopa, poultry, velvet bean, weight gain.

RESUMEN. Se evaluó el efecto de remojar semillas de Mucuna pruriens (MP) en soluciones con agua (AMP), ácido acético (AAMP) o hidróxido de calcio (HCMP) + hervido sobre su contenido de L-Dopa y el rendimiento productivo de pollos de engorda. El experimento incluyo un control sin MP (C). El tratamiento HCMP disminuyó $71 \%$ la L-Dopa comparado con AAMP $(53 \%)$ o AMP $(41 \%)$. En la fase inicial, el grupo AAMP tuvo menos ganancia de peso $(p<0.05)$ y mayor conversión alimenticia que el $C(p<0.05)$. El rendimiento productivo de los pollos alimentados con HCMP y $C$ fueron similares $(p>$ $0.05)$. En la fase final, el rendimiento productivo fue igual $(p>0.05)$. El rendimiento de canal fue similar $(p>0.05)$, pero los pollos alimentadas con AMP o AAMP presentaron un hígado más pesado que los pollos del grupo $C(p<0.05)$. Los resultados indicaron que $25 \%$ de HCMP podría incluirse como ingrediente en el alimento para pollos de engorda.

Palabras clave: Aves de corral, L-Dopa, frijol terciopelo, ganancia de peso.

\section{INTRODUCTION}

In developing countries, there is a large dependence on grains and oilseeds as the main source of protein for livestock. The high demand for these energy and protein sources causes a constant increment of grain prices. This situation has led to the search for the use of under-utilized tropical legume seeds in animal feeding. The ecological conditions prevailing in the tropical regions allow the growth of a large variety of species with nutritional potential. Legumes are a good source of crude protein (CP,
Siddhuraju and Becker 2005), amino acids (Mugendi et al. 2010), and minerals (Arrivalagan et al. 2014). Mucuna pruriens (L) DC. Var (Wight) Burck called Velvet bean is originally from tropical Asia (Huisden et al. 2014) and has high CP content, carbohydrates and acceptable levels of fiber for animal feeding (Safwat et al. 2015). This legume can be an alternative to animal nutrition. However, it contains a variety of toxic secondary metabolites such as phytates, trypsin inhibitors, L-3,4-Dihydroxyphenylalanine (L-Dopa), cyanogenic glycosides, tannins, oxalates, saponins and lectins have been identified in $M$. 
pruriens (lyayi et al. 2008), which reduce digestibility of the diet (Bath and Karin 2009).

The heat labile characteristic of some antinutritional factors reported for M. pruriens, such as cyanogenic glycosides (Acamovic and Brooker 2005), trypsin inhibitors, tannins (Siddhuraju and Becker 2001) and phenols (Preet and Punia 2000), allows their elimination with thermic treatments (Del Carmen et al. 1999, lyayi et al. 2008). L-Dopa in M. pruriens is not heat labile and solubilization is one way to eliminate it (Josephineand and Janardhanan 1992). Thus, soaking of this seed with calcium hydroxide (Safwat et al. 2015), water (Tuleun and Igba 2008) sodium bicarbonate, citric acid and tamarind extract reduces this metabolite (Siddhuraju and Becker 2001). Inclusion of $40 \%$ of MP in the starter phase and $60 \%$ in finishing phase have been reported as an adequate percentage for poultry diets (Vadivel et al. 2011). In the same way, the inclusion of boiled MP is viable up to $60 \%$ resulting in an improvement in productive performance (Tuleun et al. 2009), however when raw MP is toxid to birds (Tuleun and Igba 2008). Thus, although MP contains several secondary metabolites, some methods have been reported to be effective to eliminate most L-Dopa and other toxic secondary metabolites from the seeds, which allows its utilization in broiler diets without compromising their productive performance. Therefore, the objective of this study was to evaluate the effect of soaked Mucuna pruriens in tap water, acid or alkaline solution + boiling on its L-Dopa content and on the growth performance of broilers and carcass yield.

\section{MATERIALS AND METHODS}

\section{Study area}

The study was carried out at the poultry production facility of the Faculty of Veterinary Medicine and Animal Science, University of Yucatan, Merida, Yucatan, Mexico. Animals were kept in a poultry house with an ambient temperature between 22 $24{ }^{\circ} \mathrm{C}$ (CONAGUA 2016).

\section{Processing methods and experimental diets}

The treatments used to eliminate L-Dopa from
MP seeds were: a) soaked seeds in water; b) soaked seeds in acetic acid solution $\left(200 \mathrm{ml} \mathrm{L}^{-1} ; \mathrm{pH}=3.0\right)$ and c) soaked seeds in calcium hydroxide solution (40 $\mathrm{g} \mathrm{L}^{-1}, \mathrm{pH}=12.3$ ). Each batch was soaked during 24 $\mathrm{h}$ in plastic pots, after the seeds were rinsed with tap water until the solution residues were eliminated. The soaked seeds were boiled for $1 \mathrm{~h}$ in a metal buckets in a gas stove, and were rinsed again with water, finally the boiled seeds were dried in an electric oven for $48 \mathrm{~h}$. Then, seeds were ground in a hammer mill $($ Azteca $\AA)$ (particle size between one to two $\mathrm{mm}$ ) and stored at room temperature $\left(22-25^{\circ} \mathrm{C}\right)$ in a plastic container until diets elaboration. Four diets were formulated: A) Control without MP (C); B) $25 \%$ inclusion of soaked MP in tap water + boiling (WMP); C) $25 \%$ inclusion of soaked MP in acetic acid solution + boiling (AAMP); D) $25 \%$ inclusion of soaked MP in calcium hydroxide solution + boiling (CHMP).

\section{Mucuna pruriens and diets composition}

Chemical composition of treated MP seeds and experimental diets were determined according to AOAC (2000). The composition of treated MP seeds are shown in Table 1, and the diets used during starter and finishing phases are shown in Table 2 and 3. To determine L-Dopa content the treated MP seeds were extracted with a solvent mixture made up with acetonitrile, water and formic acid (50:50:1, respectively), the extracts obtained were analyzed using a Smartline UV Detector 2500 Knauer HPLC with a Hypersil Gold HILIC column according to Takashi et al (2011).

\section{Experimental animals}

During the experiment, 96 sexed 21 days-old Hubbard FLEX ${ }^{\circledR}$ chicks were used. The birds were divided into two blocks with 48 birds each (first block between August - September and the second block between September - October). There were 24 replicates per treatment. Similar number of males and females were assigned to each treatment. The animals were handled individually in metal cages $(40 \times 40 \times$ $40 \mathrm{~cm}$ ), when starting the trial the broiler chickens were identified and weighed. The starter phase was between week four and five of age and the finishing phase comprised week six to seven. The animals had 
Sarmiento-Franco et al.

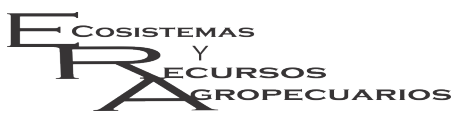

Mucuna pruriens in broiler diets

Ecosist. Recur. Agropec.

6(16):121-127,2019

Table 1. Chemical composition (\%) of treated Mucuna pruriens seeds.

\begin{tabular}{cccccc}
\hline Treatment & Dry matter & Crude protein & Ether extract & Crude fiber & Ash \\
\hline Soacked in Water & 92.01 & 21.54 & 2.75 & 7.99 & 2.15 \\
Soacked in Acid & 91.76 & 22.80 & 2.90 & 7.91 & 2.19 \\
Soacked in Alkali & 92.99 & 22.48 & 1.88 & 7.92 & 5.38 \\
\hline
\end{tabular}

Table 2. Composition (\%) and proximal analyses of experimental diets containing treated Mucuna pruriens seeds during the starter phase.

\begin{tabular}{|c|c|c|c|c|}
\hline Ingredient & Control & WMP & AAMP & CHMP \\
\hline Maize & 61.0 & 46.5 & 47.7 & 47.4 \\
\hline Mucuna pruriens seeds & - & 25.0 & 25.0 & 25.0 \\
\hline Soybean meal & 34.6 & 23.4 & 22.3 & 22.6 \\
\hline Calcium carbonate & 1.5 & 1.6 & 1.6 & 1.6 \\
\hline Calcium orthophosphate & 1.1 & 1.3 & 1.3 & 1.3 \\
\hline Vegetable oil & 1.2 & 1.3 & 1.2 & 1.2 \\
\hline Methionine 99\% & 0.1 & 0.3 & 0.3 & 0.3 \\
\hline Lysine 99\% & . & 0.2 & 0.3 & 0.3 \\
\hline $\mathrm{NaCl}$ & 0.3 & 0.3 & 0.3 & 0.3 \\
\hline Minerals premix ${ }^{1}$ & 0.1 & 0.1 & 0.1 & 0.1 \\
\hline Vitamins premix ${ }^{2}$ & 0.1 & 0.1 & 0.1 & 0.1 \\
\hline Total & 100.0 & 100.0 & 100.0 & 100.00 \\
\hline \multicolumn{5}{|c|}{ Determined analysis } \\
\hline Dry matter & 85.3 & 89.4 & 89.0 & 89.0 \\
\hline Crude protein & 21.4 & 21.4 & 21.4 & 21.4 \\
\hline Crude fiber & 0.9 & 2.1 & 2.7 & 2.4 \\
\hline Ether extract & 1.6 & 2.4 & 3.3 & 3.0 \\
\hline Ash & 6.1 & 4.7 & 3.5 & 4.4 \\
\hline \multicolumn{5}{|c|}{ Calculated analysis } \\
\hline Metabolizable energy & 3.0 & 3.0 & 3.0 & 3.0 \\
\hline Calcium & 0.8 & 0.8 & 0.8 & 0.8 \\
\hline Available phosphorus & 0.4 & 0.4 & 0.4 & 0.4 \\
\hline Sodium & 0.1 & 0.1 & 0.1 & 0.1 \\
\hline Arginine & 0.9 & 1.0 & 0.9 & 0.9 \\
\hline Lysine & 1.0 & 1.0 & 1.0 & 1.0 \\
\hline Methionine & 0.5 & 0.5 & 0.5 & 0.5 \\
\hline Meth+Cys & 0.8 & 0.8 & 0.8 & 0.8 \\
\hline Threonine & 0.6 & 0.6 & 0.6 & 0.6 \\
\hline Tryptophan & 0.2 & 0.2 & 0.2 & 0.2 \\
\hline \multicolumn{5}{|c|}{$\begin{array}{l}{ }^{1} \text { Minerals premix: manganese, } 65 \mathrm{mg} \text {; iodine, } 1 \mathrm{mg} \text {; iron, } 55 \mathrm{mg} \text {, } \\
\text { copper, } 6 \mathrm{mg} \text {; zinc, } 55 \mathrm{mg} \text {; selenium, } 0.3 \mathrm{mg} \text {. }{ }^{2} \text { Vitamins premix: vita- } \\
\text { min A, } 8,000 \mathrm{UI} \text {; vitamin D, 2,500 UI; vitamin E, } 8 \mathrm{Ul} \text {; vitamin } \mathrm{K}, 2 \mathrm{mg} \text {; } \\
\text { vitamin B12, } 0.002 \mathrm{mg} \text {; riboflavin, } 5.5 \mathrm{mg} \text {; pantothenate of calcium, } \\
13 \mathrm{mg} \text {; niacin, } 36 \mathrm{mg} \text {; choline, } 500 \mathrm{mg} \text {; folic acid, } 0.5 \mathrm{mg} \text {; thiamine, } 1 \\
\text { mg; pyridoxine, } 2.2 \mathrm{mg} \text {; biotin, } 0.05 \mathrm{mg} \text {. WMP: seeds soaked I water } \\
\text { + boiling, AAMP: seeds soaked in acid solution + boiling and CHMP: } \\
\text { seeds soaked in alkaline solition + boiling. }\end{array}$} \\
\hline
\end{tabular}

free access to water and were feed ad libitum.

\section{Growth performance}

Live weight gain (LWG) and feed intake (FI) were registered weekly. The FI was determined by difference between the offered and the consumed food, the feed conversion ratio (FCR) was calculated as the ratio between feed intake and live weight gain. At the end of the rearing periods, all birds were slaughtered
Table 3. Composition (\%) and proximal analyses of experimental diets containing treated Mucuna pruriens seeds during the finishing phase.

\begin{tabular}{|c|c|c|c|c|}
\hline Ingredient & Control & Water & Acid & Alkaline \\
\hline Corn grain & 69.0 & 54.6 & 55.8 & 55.5 \\
\hline Mucuna pruriens seeds & - & 25.0 & 25.0 & 25.0 \\
\hline Soybean meal & 26.9 & 15.5 & 14.4 & 14.7 \\
\hline Calcium carbonate & 1.4 & 1.5 & 1.5 & 1.5 \\
\hline Calcium orthophosphate & 1.1 & 1.2 & 1.2 & 1.2 \\
\hline Vegetable oil & 1.0 & 1.1 & 0.9 & 1.0 \\
\hline Methionine $99 \%$ & 0.2 & 0.3 & 0.3 & 0.3 \\
\hline Lysine $99 \%$ & 0.1 & 0.4 & 0.4 & 0.4 \\
\hline Minerals premix ${ }^{1}$ & 0.1 & 0.1 & 0.1 & 0.1 \\
\hline Vitamins premix ${ }^{2}$ & 0.1 & 0.1 & 0.1 & 0.1 \\
\hline $\mathrm{NaCl}$ & 0.3 & 0.3 & 0.3 & 0.3 \\
\hline Total & 100.0 & 100.0 & 100.0 & 100.0 \\
\hline \multicolumn{5}{|c|}{ Determined analysis } \\
\hline Dry matter & 87.8 & 89.0 & 89.1 & 89.0 \\
\hline Crude protein & 19.6 & 19.6 & 19.6 & 19.6 \\
\hline Crude fiber & 1.2 & 2.6 & 2.8 & 2.5 \\
\hline Ether extract & 2.2 & 2.8 & 2.8 & 2.4 \\
\hline Ash & 4.9 & 4.7 & 4.2 & 5.2 \\
\hline \multicolumn{5}{|c|}{ Calculated analysis } \\
\hline Metabolizable energy & 3.1 & 3.1 & 3.1 & 3.1 \\
\hline Calcium & 0.8 & 0.8 & 0.8 & 0.8 \\
\hline Available phosphorus & 0.4 & 0.4 & 0.4 & 0.4 \\
\hline Sodium & 0.1 & 0.1 & 0.1 & 0.1 \\
\hline Arginine & 0.7 & 0.7 & 0.7 & 0.7 \\
\hline Lysine & 1.0 & 1.0 & 1.0 & 1.0 \\
\hline Methionine & 0.5 & 0.5 & 0.5 & 0.5 \\
\hline Meth+Cys & 0.7 & 0.7 & 0.7 & 0.7 \\
\hline Threonine & 0.5 & 0.5 & 0.5 & 0.5 \\
\hline Tryptophan & 0.2 & 0.2 & 0.2 & 0.2 \\
\hline \multicolumn{5}{|c|}{$\begin{array}{l}{ }^{1} \text { Minerals premix: manganese, } 65 \mathrm{mg} \text {; iodine, } 1 \mathrm{mg} \text {; iron, } 55 \mathrm{mg} \text {, } \\
\text { copper, } 6 \mathrm{mg} \text {; zinc, } 55 \mathrm{mg} \text {; selenium, } 0.3 \mathrm{mg} \text {. }{ }^{2} \text { Vitamins premix: vita- } \\
\text { min A, } 8,000 \mathrm{Ul} \text {; vitamin D, 2,500 Ul; vitamin E, } 8 \mathrm{Ul} \text {; vitamin } \mathrm{K}, 2 \mathrm{mg} \\
\text { vitamin } \mathrm{B} 12,0.002 \mathrm{mg} \text {; riboflavin, } 5.5 \mathrm{mg} \text {; pantothenate of calcium, } 13 \\
\mathrm{mg} \text {; niacin, } 36 \mathrm{mg} \text {; choline, } 500 \mathrm{mg} \text {; folic acid, } 0.5 \mathrm{mg} \text {; thiamine, } 1 \mathrm{mg} \\
\text { pyridoxine, } 2.2 \mathrm{mg} \text {; biotin, } 0.05 \mathrm{mg} \text {. }\end{array}$} \\
\hline
\end{tabular}

to determine carcass yield (CY) (carcass without drumsticks and head), in addition the liver weight (LW) was recorded.

\section{Statistical analysis}

The collected data were analyzed using the General Linear Model (GLM of SAS) using a randomized complete block design (SAS 2010). The sex of the brolilers chickens was included as fixed 
effect in the statistical model. Least-Squares Means were compared using the PDIFF option of SAS when significant effects $(p<0.05)$ between treatments were detected.

\section{RESULTS AND DISCUSSION}

In this study it was found that raw seeds contained $2.0 \%$ of L-Dopa (Table 4). This value was lower than that reported by others studies (3.5 - 5.7\%) (Dahouda et al. 2009, Cassani et al. 2016). The L-Dopa content in MP has been associated to seed colors, black varieties have a higher amount of this secondary compound, whereas white varieties contain a lower percentage and mottled varieties have intermediate values (Gurumoorthi et al. 2003). Mixed seeds were used in the current study, with predominance of white seeds. Probably, for this reason L Dopa content was lower in the current study compared to earlier studies. CHMP treatment reduced $71.0 \%$ of L-Dopa content (Table 4). This result is similar to previous reports where soaked MP in sodium bicarbonate $(\mathrm{pH}=8.5)$ reduced L-Dopa 68.0\% (Gurumoorthi et al. 2003). Similarly, Ukachukwu and Szabo (2003) when soaked MP in calcium hydroxide achieved $63.0 \%$ elimination of $L$-Dopa relative to raw seeds.

Table 4. Quantification of L-Dopa in treated Mucuna pruriens seeds.

\begin{tabular}{lc}
\hline Sample & Content $\left(\mathrm{g} \mathrm{kg}^{-1}\right)$ \\
\hline Raw seeds & 20.0 \\
Seeds soaked in water + boiling & 11.8 \\
Seeds soaked in acid solution + boiling & 9.3 \\
Seeds soaked in alkaline solution + boiling & 5.8 \\
\hline
\end{tabular}

The reduction of L-Dopa content was lower in AAMP and WMP treatment (Table 4). These values are comparable to earlier reports. Siddhuraju and Becker (2001) found a reduction of $54.0 \%$ with tamarind extract and $40.0 \%$ when citric acid was used, while in other reports a reduction of only $27.0 \%$ was reached when MP was soaked in water (Diallo and Berhe 2003). The chemical structure of L-Dopa allows its elimination easier in an alkaline medium (Siddhuraju and Becker 2001). In the current study, CHMP treatment $(\mathrm{pH}=12.3)$ eliminated L-Dopa in a greater proportion than the other treatments and would be the recommended treatment for MP for inclusion in broiler diets.

The inclusion of $25.0 \%$ of treated MP in diets for broiler chickens did not affect Fl $(p>0.05)$. This inclusion level is higher than those recommended in other studies, where MP was processed with different treatments. Tuleun and Igba (2008) recommend an inclusion of up to $20.0 \%$ of soaked seeds + boiling. lyayi et al. (2008) suggest $15.0 \%$ with MP soaked in water and Akinmutimi and Okwu (2006) suggested up to $10.0 \%$ inclusion of heated MP. Young birds are more susceptible to L-Dopa because the ingestion of this compound causes a reduction of animal growth (Del carmen et al. 1999, Gurumoorthi et al. 2008). In the current study, broilers in the AAMP group had the lowest LWG and higher FCR compared to $C(p<$ 0.05). Nevertheless, although the broilers from AAMP treatment had the lowest daily live weight gain, this was superior to the $41.8 \mathrm{~g}_{\text {day }^{-1}}$ reported by Tuleun et al. (2011).

When the three groups offered MP are compared, no significant differences were found for LWG and FCR $(p>0.05)$, however broilers growth in the CHMP treatment was similar to $C(p>0.05)$. These results suggest that CHMP treatment improved MP nutritive value. According to Tuleun and Patrick (2007), soaking and boiling MP seeds increases the digestibility of protein and carbohydrates compared to raw seeds and when soaking is realized in an alkaline solution it is further improves due to higher elimination of L-Dopa, thus reducing its negative effect on birds (Siddhuraju and Becker 2001).

During the finishing phase, there were not statistical differences $(p>0.05)$ in Fl, LWG and FCR between treatments (Table 6). These results indicate that up to $25.0 \%$ of treated MP could be used in broiler diets without affecting the performance. This level of inclusion is higher to that recommended by Vadivel and Pugalenthi (2010) with soaked MP in a sodium bicarbonate solution + autoclaving (11\%). Others have suggested up to $10.0 \%$ of heated MP without negative effects (Del Carmen et al. 1999) or up to $6.0 \%$ of roasted MP (Emenalom and Udedibie 1998). Other authors have suggested levels not higher than $20.0 \%$ when using soaked MP in water + boiling, 
Table 5. Productive performance of broiler chicks fed diets containing Mucuna pruriens seeds treated with water, an acid solution and an alkaline solution during the starter phase. Values are least square means values \pm standard deviation.

\begin{tabular}{ccccc} 
Treatments & $\begin{array}{c}\text { Initial live weight } \\
(\mathrm{kg})\end{array}$ & $\begin{array}{c}\text { Feed intake } \\
(\mathrm{kg})\end{array}$ & $\begin{array}{c}\text { Live weight gain } \\
(\mathrm{kg})\end{array}$ & $\begin{array}{c}\text { Feed conversion } \\
\text { ratio }\end{array}$ \\
\hline Control & $0.71 \pm 0.080^{a}$ & $1.82 \pm 0.215^{a}$ & $1.03 \pm 0.129^{a}$ & $1.78 \pm 0.143^{b}$ \\
WMP & $0.73 \pm 0.088^{a}$ & $1.76 \pm 0.170^{a}$ & $0.95 \pm 0.095^{a b}$ & $1.86 \pm 0.148^{a b}$ \\
AAMP & $0.70 \pm 0.089^{a}$ & $1.76 \pm 0.249^{a}$ & $0.94 \pm 0.149^{b}$ & $1.90 \pm 0.289^{a}$ \\
CHMP & $0.75 \pm 0.060^{a}$ & $1.80 \pm 0.222^{a}$ & $0.98 \pm 0.132^{a b}$ & $1.83 \pm 0.101^{a b}$ \\
\hline
\end{tabular}

Table 6. Productive performance during the finishing phase and carcass yield of broiler chicks fed diets containing $\mathrm{Mu}$ cuna pruriens seeds treated with water, an acid solution and an alkaline solution. (Least square means values \pm standard deviation).

\begin{tabular}{lcccccc}
\hline Treatments & $\begin{array}{c}\text { Feed intake } \\
(\mathrm{kg})\end{array}$ & $\begin{array}{c}\text { Liveweight gain } \\
(\mathrm{kg})\end{array}$ & $\begin{array}{c}\text { Feed conversion } \\
\text { Ratio }\end{array}$ & $\begin{array}{c}\text { Carcass yield } \\
(\%)\end{array}$ & $\begin{array}{c}\text { Liver weight } \\
(\mathrm{g})\end{array}$ & $\begin{array}{c}\text { Liver }(\mathrm{g}) \\
\text { / carcass }(\mathrm{kg})\end{array}$ \\
\hline Control & $2.3 \pm 0.3^{a}$ & $1.0 \pm 0.1^{a}$ & $2.3 \pm 0.2^{a}$ & $77.1 \pm 3.5^{a}$ & $47.7 \pm 7.2^{a}$ & $22.4 \pm 3.4^{b}$ \\
WMP & $2.4 \pm 0.4^{a}$ & $0.9 \pm 0.2^{a}$ & $2.4 \pm 0.2^{a}$ & $76.3 \pm 2.9^{a}$ & $49.3 \pm 10.1^{a}$ & $24.6 \pm 4.5^{a}$ \\
AAMP & $2.4 \pm 0.3^{a}$ & $1.0 \pm 0.2^{a}$ & $2.4 \pm 0.3^{a}$ & $75.6 \pm 3.3^{a}$ & $50.1 \pm 10.5^{a}$ & $25.1 \pm 3.9^{a}$ \\
CHMP & $2.4 \pm 0.3^{a}$ & $1.0 \pm 0.2^{a}$ & $2.4 \pm 0.2^{a}$ & $76.4 \pm 3.2^{a}$ & $50.9 \pm 6.4^{a}$ & $24.4 \pm 3.2^{a b}$ \\
\hline \multicolumn{2}{l}{ Means within the same column with different superscripts differ $(\mathrm{p}<0.05)}$.
\end{tabular}

or fermented (Tuleun et al. 2009, Tuleun et al. 2011). The results obtained during this growing phase suggest that WMP, AAMP or CHMP treatments were sufficient to reduce L-Dopa present in MP, and the broiler performance was not affected.

Table 6 shows the data regarding the carcass yield. Broilers had an average carcass yield of $76.0 \%$ without statistical differences between treatments $(p$ $>0.05$ ) However, birds fed with WMP or AAMP had heavier livers than the $C$ group $(p<0.05)$. There were not differences in liver weight between broilers fed CHMP in comparison to those in the $C$ group $(p>$ 0.05). According to Emenalom and Udedibie (1998) and Emenalom and Nwachukwu (2006) toxic compounds in the diet causes an increase in liver size. However, no effect on growth performance was observed in broilers fed MP in the present experiment. Due to the higher growth rates of broiler in a short period of time the MP content after treatment possibly did not affect the broiler performance in the finishing phase, but a long term effect might be observed if broilers are fed MP for longer periods of time. These aspects warrant further research to assess the effect of feeding MP in laying hens which are fed during longer periods.

The alkaline solution was the most effective treatment to reduce L-Dopa from $M$. pruriens seeds. Broilers fed MP soaked seeds in acetic acid solution had lower growth rate during the starter phase. Nevertheless, the presence of L-Dopa in the diet did not affect negatively the performance of broilers during the finishing phase; therefore $25.0 \%$ of $M$. pruriens seeds soaked in alkaline solution and boiled could be included in broiler diets without unfavorable effects on feed intake, live weight gain and feed conversion ratio.

\section{ACKNOWLEDGEMENTS}

This work was founded by PRODEP (Red Tematica 2015) and CONACYT (INFR-2016-01269108).

\section{LITERATURE CITED}

Acamovic T, Brooker J (2005) Biochemistry of plant secondary metabolites and their effects in animals. Proccedings of the Nutrition Society 64: 403-412. 
Akinmutimi AH, Okwu ND (2006) Effect of quantitative substitution of cooked Mucuna utilis seed meal for soybean meal in broiler finisher diet. International Journal of Poultry Science 5: 477-481.

AOAC (2000) Official methods of analysis, 17th ed. Washington, USA. 2200p.

Arrivalagan M, Prasad T, Singh H, Kumar A (2014) Variability in biochemical and mineral composition of Mucuna pruriens (L.) DC. - An underutilized tropical legume. Legume Research 37: 483-491.

Bhat R, Karim A (2009) Exploring the nutritional potential of wild and underutilized legumes. Compremhensive Reviews in Food Science and Food Safety 8: 305-331.

Cassani E, Cilia R, Laguna J, Barichella M, Contin M, Cereda E, et al. (2016) Mucuna pruriens for parkinson's disease: low-cost preparation method, laboratory measures and pharmacokinetics profile. Journal of the Neurological Science 365: 175-180.

CONAGUA (2016) Resumenes mensuales de temperaturas y lluvias enero a diciembre 2016. Reporte del clima en México. https://smn.cna.gob.mx/es/climatologia/temperaturas-y-lluvias/resumenes-mensuales-detemperaturas-y-lluvias. Date consulted: june 1, 2017.

Dahouda M, Toléba SS, Youssao AKI, Hambuckers A, Dangou-Sapoho R, Martin GB, et al. (2009) Nutrient digestibility of mucuna (Mucuna pruriens var. utilis) bean in guinea fowl (Numida meleagris, L): Effects of heat treatment and levels of incorporation in diets. British Poultry Science 50: 564-572.

Del Carmen J, Gernat A, Myhrman R, Carew LB (1999) Evaluation of raw and heated velvet beans (Mucuna pruriens) as feed ingredients for broilers. Poultry Science 78: 866-872.

Diallo OK, Berhe T (2003) Processing of mucuna for human food in the republic of Guinea. Tropical and Subtropical Agroecosystems 1: 193-196.

Emenalom O, Udedibie ABI (1998) Effect of dietary raw, cooked and toasted mucuna pruriens seeds (velvet bean) on the performance of finisher broilers. Nigerian Journal of Animal Production 25: 115-119.

Emenalom OO, Nwachukwu IC (2006) Effect of calcium hydroxide soaked and cooked velvet beans (Mucuna pruriens) on the performance of finisher broilers. Nigerian Journal of Animal Production 33: 53-57.

Gurumoorthi P, Janardhanan K, Myhrman R (2008) Effect of differential processing methods on I-dopa and protein quality in velvet bean, an underutilized pulse. LWT - Food Science and Technology 41: 588-596.

Huisden CM, Szabo NJ, Ogunade IM, Adesogan AT (2014) Mucuna pruriens detoxification: effects of ensiling duration and particle size. Animal Feed Science and Technology 198: 20-27.

lyayi EA, Kluth H, Rodehutscord M (2008) Effect of heat treatment on antinutrients and precaecal crude protein digestibility in broilers of four tropical crop seeds. International Journal of Food Science and Technology 43: 610-616.

Josephine RM, Janardhanan K (1992) Studies on chemical composition and antinutritional factors in three germplasm seed materials of the tribal pulse, Mucuna pruriens (L.) DC. Food Chemestry 43: 13-18.

Mugendi J, Njaji E, Kuria E, Mwasaru M, Mureithi J, Spostolides Z (2010) Effects of processing methods on the protein quality of mucuna bean. African Journal of Food Agriculture Nutrition and Development 10: 2394-2412.

Preet K, Punia D (2000) Antinutrients and digestibility (In vitro) of soaked, dehulled and germinated cowpeas. Nutrition and Health 14: 109-117. 
Safwat AM, Sarmiento-Franco L, Santos-Ricalde RH, Nieves D, Magaña-Sevilla H (2015) Effect of dietary inclusion of processed Mucuna pruriens seed meal on growing rabbits. Animal Feed Science and Technology 201: $72-79$.

SAS (2010) SAS User's Guide: Statistics. Ver 9.3. 4th ed. SAS Institute. Cary, North Carolina, USA. 2340p.

Siddhuraju P, Becker K (2001) Effect of various domestic processing methods on antinutrients and in vitro protein and starch digestibility of two indigenous varieties of indian tribal pulse, Mucuna pruriens Var. utilis. Journal of Agricultural and Food Chemestry 49: 3058-3067.

Siddhuraju P, Becker K (2005) Nutritional and antinutritional composition, in vitro amino acid availability, starch digestibility and predicted glycemic index of differentially processed mucuna beans (Mucuna pruriens var. utilis): An Under-utilized Legume. Food Chemestry 91: 275-286.

Takashi H, Takahashi I, SaijoMassaki K, Tomohide F, Tomoko N, Yuji M (2011) Quantitative determination of Idopa in dietary supplements containing mucuna pruriens by high performance liquid chromatography. Chiba Prefecture Wei Yan Annual Report 60: 53-56.

Tuleun CD, Adenkola AY, Orayaga KT (2011) Naturally fermented mucuna seed meal based diets: Effect on performance and carcass characteristics of broiler chickens. Research Journal of Poultry Science 4: 50-55.

Tuleun CD, Igba F (2008) Growth and carcass characteristics of broiler chickens fed water soaked and cooked velvet bean (Mucuna utilis) meal. African Journal of Biotechnology 7: 2676-2681.

Tuleun CD, Patrick JP (2007) Effect of duration of cooking Mucuna utilis seed on proximate analysis, levels of antinutritional factors and performance of broiler chickens. Nigerian Society for Animal Production 34: 45-53.

Tuleun CD, Patrick JP, Tiamiyu LO (2009) Evaluation of raw and boiled velvet bean (mucuna utilis) as feed ingredient for broiler chickens. Pakistan Journal of Nutrition 8: 601-606.

Ukachukwu SN, Szabo NJ (2003) Effect of processing, additives and vitamin B6 supplementation of Mucuna pruriens var cochinchinensis on broilers. Tropical and Subtropical Agroecosystems 1: 227-237.

Vadivel V, Pugalenthi M (2010) Evaluation of growth performance of broiler birds fed with diet containing different levels of velvet bean meal as an alternative protein ingredient. Livestock Science 127: 76-83.

Vadivel V, Pugalenthi M, Doss A, Parimelazhagan T (2011) Evaluation of velvet bean meal as an alternative protein ingredient for poultry feed. Animal 5: 67-73. 
